\title{
Multi-scale habitat use analysis and interspecific Ecology of the Critically Endangered Black-breasted Puffleg Eriocnemis nigrivestis
}

\author{
ESTEBAN A. GUEVARA, ELISA BONACCORSO and \\ JOOST F. DUIVENVOORDEN
}

\section{Summary}

The Black-breasted Puffleg Eriocnemis nigrivestis is a hummingbird endemic to Ecuador and considered Critically Endangered, given its limited distribution, low population numbers, and ongoing habitat degradation. We investigated habitat use patterns using landscape and microhabitat variables. In addition, we explored a previously postulated competition hypothesis involving the Black-breasted Puffleg and the Gorgeted Sunangel Heliangelus strophianus. Our results suggest that landscape variables may play a role in the habitat selection process; specifically the distance to nearest forest border seems to have a significant effect on our habitat model. We speculate that, as the species is known to perform seasonal movements, the avoidance of forest border might reduce the physiological stress caused by altitudinal migration. At microhabitat level, Black-breasted Puffleg seems not sensitive to forest structure variables. Our findings suggest that ensuring forest tract connectivity, between the altitudinal extremes of the species' range at the north-western flanks of the Pichincha volcano, might be crucial for survival of the species during its annual cycle. However, non-metric multidimensional scaling (NMDS) indicates that Black-breasted Puffleg and the Gorgeted Sunangel do not overlap spatially, but this finding is not conclusive considering our field observations.

\section{Resumen}

Eriocnemis nigrivestis es un colibrí endémico de Ecuador, considerado Críticamente Amenazado debido a su distribución restringida, reducido tamaño poblacional y pérdida continua de su hábitat. Investigamos los patrones de uso de hábitat por parte de la especie, empleando variables a nivel de paisaje y micro hábitat. Adicionalmente exploramos la hipótesis de competencia entre Eriocnemis nigrivestis y Heliangelus strophianus que ha sido previamente postulada. Nuestros resultados sugieren que las variables de paisaje como la distancia al borde de bosque más cercano tendrían un rol en el proceso de selección de hábitat. Especulamos que la especie, en términos generales, evite los bordes de bosque con el fin de reducir el ya existente estrés fisiológico que la migración altitudinal conlleva. A nivel de microhábitat, Eriocnemis nigrivestis aparentemente no responde a las variables relacionadas con la estructura del bosque. Nuestros resultados también sugieren que para incrementar las probabilidades de sobrevivencia de la especie es necesario asegurar la conectividad entre fragmentos de bosque ubicados a lo largo del rango altitudinal de la especie en los flancos nor-occidentales del volcán Pichincha. Por otro lado, a pesar de que nuestros hallazgos indican que Eriocnemis nigrivestis y Heliangelus strophianus no se solapan espacialmente, pensamos que estos resultados no son concluyentes considerando nuestras observaciones de campo.

\section{Introduction}

Hummingbird species of the Eriocnemis genus inhabit a wide range of habitats including forest, borders, and sub-paramo in the subtropical and temperate zones of the Andes, ranging at altitudes 
of $\sim 1000-5000 \mathrm{~m}$ (Schuchmann et al. 2001, Cortes-Diago et al. 2007). One of those species is the Black-breasted Puffleg Eriocnemis nigrivestis, which is endemic to Ecuador and regarded as 'Critically Endangered' (BirdLife International 2012). Two arguments support this conservation status. The first is its limited global distribution $\left(\sim 68 \mathrm{~km}^{2}\right)$ which is divided into two confirmed subpopulations, one on the north-western flanks of Pichincha volcano, in Pichincha province, and the other located in the Toisan mountain range in Imbabura province (BirdLife International 2012). Jahn (2008) reported historical specimens collected at Atacazo volcano, in Pichincha province; however, there are no recent surveys confirming the persistence of this population. The second argument is its small population size, recently estimated in the range of 250-999 individuals (Jahn 2008).

Little information on the ecological requirements (e.g. nest and foraging site selection) of the Black-breasted Puffleg has been published to date (but see Jahn 2008), probably because of its scarcity and elusive habits. Bleiweiss and Olalla (1983) have referred to ridge-crest elfin forest as Black-breasted Puffleg habitat. However, recent information indicates that the species may also be found in shrubby forest borders, steep slopes with stunted vegetation, and the interior of mature montane forest (Jahn and Santander 2008). In any case, the species' presence seems not to be determined by the occurrence of a particular feeding plant since it has been recorded feeding at a wide range of ornitophilous plant species (Bleiweiss and Olalla 1983, Jahn and Santander 2008).

Habitat use is considered the result of the habitat selection process in which individuals choose the habitat that provides environmental conditions appropriate for survival, reproduction, and population persistence (Boyce and McDonald 1999). Research on habitat use by terrestrial threatened bird species has shown that fine-scale features of forest physiognomy might be relevant in discriminating patterns in habitat usage (Bonaccorso and Barreto 2002, Oppel et al. 2004, Cahill and Matthysen 2007). Nevertheless, habitat selection may be seen as a spatially hierarchical process (Johnson 1980), in which species choose suitable conditions first at a broader scale (e.g. landscape) and then at a more narrow scale (microhabitat). Therefore, a complete habitat assessment may include multiple scales of research (McClure et al. 2012). Along the distributional range of the Black-breasted Puffleg, formerly pristine habitat has been heavily disturbed, especially because of the expansion of the agricultural frontier and human-induced burning of grassland and forest habitats (Jahn and Santander 2008). This situation has given rise to a matrix of different landscapes including forest patches, cattle pastures, and forest borders, making habitat assessments at different spatial scales essential for planning conservation efforts.

The way in which species that exploit similar resources coexist in space and time is a central matter in community ecology (Martin 2001, Sheth et al. 2009). Several mechanisms such as habitat selection, spatial distribution, and morphological differentiation have been proposed to explain the coexistence of organisms and the maintenance of community assemblages (Stevens and Willig 2000, Martin 2001). Recently, concern has been raised over the apparent altitudinal range extension of the Gorgeted Sunangel Heliangelus strophianus, a species that could be a potential competitor to the Black-breasted Puffleg (Jahn 2008, Jahn and Santander 2008). Determining whether the more widely distributed Gorgeted Sunangel is a better competitor might contribute to an understanding of recent declines in the abundance of the 'Critically Endangered' Black-breasted Puffleg. In this study we aim to test hypotheses on whether the Black-breasted Puffleg responds to microhabitat and landscape variables, measured as vegetation structure and distance to nearest forest border respectively. In addition we explore potential competition among Black-breasted Puffleg and other hummingbird species in hummingbird communities.

\section{Methods}

\section{Study area}

The study area is located on the north-western flanks of the Pichincha volcano, Pichincha province, north-western Ecuador, covering an altitudinal range of 2,700-3,500 m (Figure 1 ); it lies within the Mindo Important Bird Area (IBA; Freile and Santander 2005) and two natural formations are 


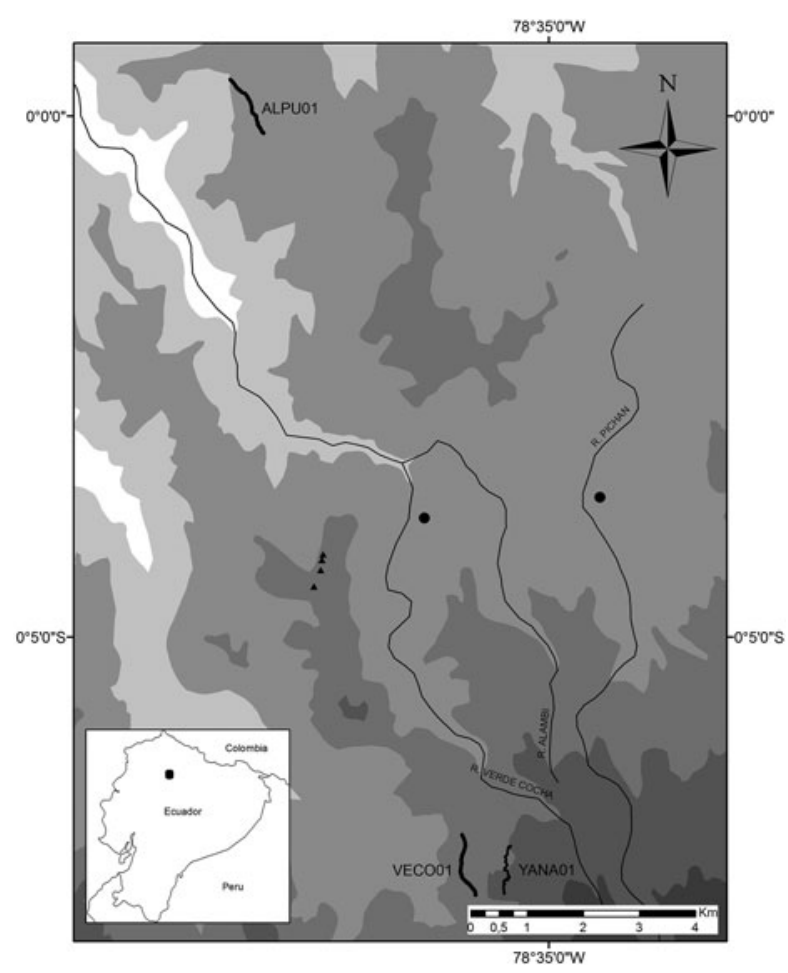

Figure 1. Location map of the four study sites on the north-western flanks of the Pichincha volcano, Pichincha province, Ecuador. Elevation ranges in $\mathrm{m}$ are represented by grey gradient colours, from darkest grey to lightest: $>3,400,3,000-3,400,2,400-3,000,2,000-2,400$ and $<2000$. Thin black lines = rivers; thick black lines = study transects; black triangles $=$ record sites at Esperanza Hill and black circles $=$ towns.

identified: montane cloud forest and evergreen high-mountain forest (Sierra 1999). We established three $1.2-\mathrm{km}$ transects at three different sites within our study area: I) Yanacocha reserve 2) Verdecocha reserve and 3) Alaspungo community reserve. All transects were at a minimum distance of $500 \mathrm{~m}$ from each other. Our study sites further included the Esperanza hill, where the Black-breasted Puffleg has also been recorded during observations performed outside the study transects. Details of coordinates and the elevation of each transect and Esperanza hill are provided in Tableı. Appendix $S_{1}$ in the online supplementary material summarises all Black-breasted Puffleg and Gorgeted Sunangel records at these sites.

\section{Bird surveys}

Bird censuses were performed applying the "multi-time window transect-mapping" (MTW) protocol for audio-visual monitoring studies (Jahn 2011). A complete survey session according MTW methodology consisted of 24 samples at each transect, accomplished within a minimum of six days (four samples per day). A sample, according to the MTW protocol, consists of an observation walk along the entire transect route in one direction (Jahn 2011). The duration of a sample may vary according to the time of day and bird activity, hence the shortest sample lasted one hour and the longest approximately four hours. Transects were sampled both on the way in as well as on the way back. Censuses included predawn to after-dusk periods $\left(\sim \mathrm{O}_{4} \mathrm{~h}_{30}\right.$ to $\left.18 \mathrm{~h}_{3} \mathrm{O}\right)$, because we aimed to survey the entire bird communities of the 
transect areas. The birds were mapped with the aid of a transect pathway map and landmarks placed on the transect route at $25 \mathrm{~m}$ intervals. Perpendicular distance to the transect route at which each bird was recorded, was estimated visually. In the present study, records of hummingbirds beyond $25 \mathrm{~m}$ were not taken into account for practical reasons. Transects were visited in the years 2007 and 2009 (Table 1 ). We included the Esperanza Hill as study site, also located on the north-western flanks of the Pichincha volcano (Figure I), where the Black breasted Puffleg was recorded during non-standardised observations in 2011. A total observation effort of $290 \mathrm{~h}$ was achieved.

\section{Habitat measurements}

On each transect section where the Black-breasted Puffleg was recorded, the habitat structure was measured following the methodology of James and Shugart (1970). We fixed plots with a radius of $12.5 \mathrm{~m}$. Further, we randomly selected transect segments where the Black-breasted Puffleg was not recorded as absence plots for habitat measurements. At each plot, the following forest structure variables were recorded: density and diameter at breast height ( $\mathrm{dbh}$ ) of all stems with $\mathrm{dbh} \geq 2.5 \mathrm{~cm}$; tree height (estimated visually for trees with $\mathrm{dbh} \geq 2.5 \mathrm{~cm}$ ), canopy cover (mean percentage of five measures with a spherical densitometer; Lemmon 1956), and shrub density (counts of all woody stems $<4 \mathrm{~m}$ in height, along two perpendicular $12.5 \times 2 \mathrm{~m}$-transects through the centre of the plot). Subsequently, for each plot stem, basal area (for each stem defined as $\pi \mathrm{x} \mathrm{dbh}^{\wedge} 2$; Larsden 1997) and canopy height (mean of all tree heights) were calculated. In total we measured the habitat structure of 19 Black-breasted Puffleg foraging plots and 31 randomly selected absence plots (see Table S1). Furthermore, we employed the distance to the nearest forest border with adjacent habitat patch (e.g. grassland-paramo, cultivated areas) larger than 100 ha, as an explanatory variable that might have an effect on habitat use at the landscape level. Values per each plot were obtained using the distance function in the ArcGIS ver. 1o Spatial Analyst tools and the vegetation map of the Metropolitan District of Quito (MDMQ-Secretaría de Ambiente 2011; scale 1 : 50,000). The same methods were applied to assess habitat variables at record points on Esperanza Hill.

\section{Numerical analysis of habitat use}

Forest structure variables at each plot were checked for normality applying a Shapiro-Wilk's test (Shapiro and Wilk 1965) and then square root transformed. These kinds of variables often exhibit high correlation at plot level (Cahill and Matthysen 2007). Therefore, in order to avoid multicollinearity and over-parametrization (Burnham and Anderson 2002) in further analyses of Black-breasted Puffleg response, we first applied principal component analyses (PCA) to vegetation data to obtain a composite measure of forest structure variation (Graham 2003). The scores of the first principal component $\left(\mathrm{PC}_{\mathrm{I}}\right)$ were used as an explanatory variable in the subsequent regression analysis.

We used presence/absence data of the species at each plot as a response variable to be explained by forest habitat structure. During exploratory analyses, relationships among the response and explanatory variables looked distinctively linear and the variance among sites differed substantially; therefore we applied generalized linear mixed models (GLMM; Bolker et al. 2009; Zuur et al. 2009). The initial model was as follows: Model $I=\operatorname{glmm}\left(B B P \sim \mathrm{PC}_{I}{ }^{*} \mathrm{DB}\right.$, random $=\sim$ Altitude $\mid$ Site,

Table 1. Coordinates, elevation and survey effort at each study site. At each transect the altitudinal range in metres asl is shown, survey dates accounts for months were bird monitoring was performed.

\begin{tabular}{lcclcc}
\hline \multicolumn{1}{c}{ Site } & Transect Code & Coordinates & Elevation $(\mathrm{m})$ & \multicolumn{1}{c}{ Survey dates } & Survey effort $(\mathrm{h})$ \\
\hline Alaspungo & ALPUo1 & $0.00175 /-78.63097$ & $2,700-3,000$ Apr, Jun 2007 & 80 \\
Verdecocha & VECOo1 & $-0.12069 /-78.59772$ & $3,386-3,435$ Mar, Jun 2007, Apr 2009 & 120 \\
Yanacocha & YANAo1 & $-0.12108 /-78.59028$ & $3,481-3,541$ Mar, May 2007 & 80 \\
Esperanza Hill & NA & $-0.07258 /-78.61981$ & 3,252 & Jul, Aug 2011 & 10 \\
\hline
\end{tabular}


family = binomial). This model tests the response of presence/absence data to PCI and log-distance to nearest forest border (DB), as well as their interaction. The 'random $=\sim$ Altitude $\mid$ Site' part implies that altitude and site were allowed to have random effects on the response. We considered this random component because our data is nested in four different sites or, in other words, explanatory variables are correlated within each site and no such correlation exists among sites. Including random effects aims to account for this source of variation while not testing for it (Zuur et al. 2009). The 'family = binomial' part implies the use of a binomial identity link. Since our sample size was rather small, we preferred not to include additional explanatory variables (e.g. PC2) in order to avoid model over-parameterization. We perform model validation by plotting residuals against fitted values or explanatory variables. The residuals did not deviate strongly from normality (visual inspection of quantile-quantile $Q-Q$ plots per site) for the habitat model.

\section{Numerical analysis of hummingbird community observations}

Non-metric multidimensional scaling (NMDS) was employed to characterise hummingbird communities at the three study sites where both Black-breasted Puffleg and Gorgeted Sunangel are known to occur, namely Verdecocha and Alaspungo reserves and Esperanza hill. We applied NMDS to a presence/absence matrix of nine hummingbird species. NMDS is an ordination technique that reduces objects (species and plots in our case) to a low dimension space; the optimal solution is found by the iterative minimisation of the difference (stress) between the original (objects) and a distance matrix (Kruskal 1964), which in our case is a Raup-Crick distance matrix (Raup and Crick 1979). Raup-Crick metrics have been previously applied to community ecology studies and is suitable for presence/ absence data like ours (Chase et al. 2011). For this analysis we included information from all plots, including those where no habitat measures were made, leading to a total of 102 plots.

All numerical analyses were performed using R 2.14.I (R Development Core Team 2011) applying the MASS (Venables and Ripley 2002), 'vegan' (Oksanen et al. 2012), and 'lattice' (Sarkar 2008) packages.

\section{Results}

The Black-breasted Puffleg was recorded in 15 different transect plots: five in YANAo1, four in ALPUoI and six in VECOoI. In addition the species was recorded at four different plots on Esperanza Hill. On the other hand, the Gorgeted Sunangel was recorded in 27 different transect sections in ALPUo1, at two sites in VECOoI and one in YANAor. Table S1 summarises all Blackbreasted Puffleg and Gorgeted Sunangel observations.

\section{Habitat Use}

Variation measures of each explanatory variable in Black-breasted Puffleg presence plots $(n=19)$ are summarised in Table 2. In the In the PCA analyses, $\mathrm{PC}_{1}$ and $\mathrm{PC}_{2}$ together explained almost $80 \%$ of the variance in forest structure data. PCI ( $53 \%$ of explained variance) was characterised by negative factor loadings for basal area (-0.61), canopy height (-0.42) and tree density $(-0.47)$, whereas a positive value was found for shrub density (0.47). Regression analyses of Model I revealed a significant effect of the log-distance to nearest forest border $(P<0.015)$ on Blackbreasted Puffleg presence, whereas no significant effect of forest structure or its interaction with the log-distance to forest border was found (Table 3).

\section{Interspecific ecology}

The NMDS ordination resulted in a 2-axis optimal solution, with final stress value of $5.7 \mathrm{e}-05$. Black-breasted Puffleg and Gorgeted Sunangel were not grouped close in the ordination plot. Instead, Black-breasted Puffleg appeared close to the Tyriant Metaltail Metallura tyrianthina (Figure 2). 
Table 2. Measures of the microhabitat and landscape variables along the 19 plots were the Black-breasted Puffleg was detected and the 31 absence plots. DB $=$ Distance to nearest forest border.

\begin{tabular}{|c|c|c|c|c|c|}
\hline \multirow[t]{2}{*}{ Variable } & \multicolumn{2}{|c|}{ Presence Plots $(\mathrm{n}=19)$} & \multicolumn{2}{|c|}{ Absence Plots $(n=31)$} & \multirow[b]{2}{*}{ Units } \\
\hline & Mean & SD & Mean & SD & \\
\hline Basal area & 0.26 & 0.015 & 0.03 & 0.01 & $\mathrm{~m} / \mathrm{ha}$ \\
\hline Canopy height & 7.88 & 1.36 & 8.63 & 1.17 & $\mathrm{~m}$ \\
\hline Shrub density & 0.18 & 0.37 & 0.64 & 0.34 & $\mathrm{ind} / 100 \mathrm{~m}^{2}$ \\
\hline Tree density & 0.77 & 0.45 & 0.91 & 0.31 & ind/491 $\mathrm{m}^{2}$ \\
\hline DB & 2.03 & 0.5 & 1.86 & 0.6 & $\mathrm{~km}$ \\
\hline Elevation & $3,298.63$ & 225.2 & 3,228 & 315.7 & $\mathrm{~m}$ asl \\
\hline
\end{tabular}

\section{Discussion}

Given the fact that our study is based on a limited number of observations obtained at a few sites we have to regard our findings as preliminary. Some aspects of Black-breasted Puffleg ecology deserve follow-up studies that we discuss below. Nevertheless, we believe that the information presented here can guide further research and conservation actions.

\section{Black-breasted Puffleg habitat use}

At the landscape level, results from the habitat use model suggest that distance to forest borders may play a critical role in habitat choice by the Black-breasted Puffleg. This is supported by results in Table 2 where mean values of distance to nearest forest border are higher in presence plots. Even though the species has been recorded foraging at flowering shrubs in forest borders (Bleiweiss and Olalla 1983, Jahn and Santander 2008), we believe that it might be a reflection of the limited number of observations in the forest interior rather than the result of optimal habitat choice process. Forest border effects on bird ecology have been hypothesised to increase individual density, nest predation (Marini et al. 1995, Hagan et al. 1996) and physiological stress resulting from abrupt changes in microclimate (Murcia 1995, Soursa et al. 2004); however, there is still debate regarding the empirical evidence supporting these hypotheses (Lahti 2001).

Nevertheless, forest borders could impose additional physiological stress on Black-breasted Puffleg as has been observed in other bird species (Soursa et al. 2004). The species is known to perform seasonal movements along an altitudinal gradient (Jahn 2008, Jahn and Santander 2008) and large non-forest landscapes represent interruptions within otherwise continuous forest tracts. Thus, we find it plausible that the species tends to avoid forest borders in order to minimise the physiological stress that migration entails (McWilliams et al. 2004), but this hypothesis should be further investigated. Observations at forest borders might represent individuals using suboptimal habitat. For instance, Jahn (2008) reported that the species was recorded on a daily basis during an eight-day survey period inside Cotacachi-Cayapas Ecological Reserve (presumably within a fairly large forest tract) and up to four different individuals were spotted each day. To the best of our knowledge, this kind of abundance is never seen at forest borders.

Table 3. Results of Generalized Linear Mixed modeling analysis for Black-breasted Puffleg habitat use. $\mathrm{PC}_{\mathrm{I}}=$ First Axes of Principal Component Analysis on vegetation structure, Logfd = logarithm of distance to nearest forest border.

\begin{tabular}{llllrl}
\hline Parametric terms & Value & SE & df & $t$-value & $P$-value \\
\hline (Intercept) & 2.665 & -1.177 & 43 & -2.264 & 0.029 \\
predictedPCI & 0.759 & 0.437 & 43 & 1.736 & 0.090 \\
logfd & 4.802 & 1.902 & 43 & 2.524 & 0.015 \\
predictedPCI ${ }^{*} \operatorname{logfd}$ & 0.029 & 0.684 & 43 & 0.043 & 0.966 \\
\hline
\end{tabular}




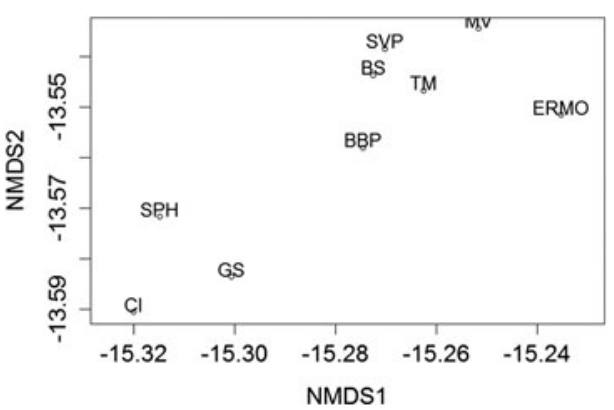

Figure 2. Non-metric multidimensional scaling ordination plot of nine hummingbird species recorded in 151 plots, along four study sites on the north-western flanks of Pichincha volcano. Species legend: BBP = Black-breasted Puffleg Eriocnemis nigrivestis; BS = Buff-winged Starfrontlet Coeligena lutetiae; $\mathrm{CI}=$ Collared Inca Coeligena torquata; $\mathrm{GBP}=$ Goldenbreasted Puffleg Eriocnemis mosquera; GS = Gorgeted Sunangel Heliangelus strophianus; $\mathrm{MV}=$ Mountain Velvetbreast Lafresnaya lafresnayi; SPH = Speckled Hummingbird Adelomyia melanogenys; SVP = Saphire-vented Puffleg Eriocnemis luciani; $\mathrm{TM}=$ Tyriant Metaltail Metallura tyrianthina.

On the other hand, at microhabitat level, forest structure variables seem not relevant for the Black-breasted Puffleg, at least when we test for the response of presence/absence data (Table 3). The Black-breasted Puffleg is known to feed on a wide number of flowering plants (29 species belonging to 11 families) with different flower morphology and life forms such as vines, shrubs, herbs and epiphytes (Bleiweiss and Olalla 1983, Jahn and Santander 2008). Our results on foraging habitat assessment together with previous knowledge on Black-breasted Puffleg food-plants may suggest that the species is not linked to specific microhabitat conditions, where more narrow plant diversity exists. Instead these figures suggest generalist behaviour regarding its feeding ecology. However, it has been proposed that the species' seasonal movements might be related to staggered flowering periods of ornitophilous plants along an altitudinal gradient (Jahn 2008).

\section{Black-breasted Puffleg and hummingbird community}

Results of NMDS ordination (Figure 2) shows that Black-breasted Puffleg and Gorgeted Sunangel do not overlap spatially at the plot scale, although both species were present on the same transects. It is yet to be determined if the pattern found is due to different habitat preferences or rather interspecific competition. For instance, if one of the two species is dominant over the other then it is to be expected that they rarely occur in the very same plot. In this case, the less dominant hummingbird simply may have to move to suboptimal habitat. The Gorgeted Sunangel has been recently recorded on the VECOor transect at an altitude of $3,390 \mathrm{~m}$, which is well beyond its previously known upper altitudinal limit (3,000 m; Ridgely and Greenfield 2001). The appearance of a previously unknown competitor for the Blackbreasted Puffleg certainly represents an additional limiting factor for the species since the puffleg might not be adapted for competition with the Gorgeted Sunangel. During our observations in 2007 on the ALPUoI transect we recorded two aggressive interactions between two males of both species in feeding territories. We consider that competition between these two species still needs to be studied through observations of agonistic behaviour. Also an assessment of habitat used by the Gorgeted Sunangel (including the main foraging stratum) might shed light on the competition hypothesis. 


\section{Implications for conservation and future research}

Distance to the nearest forest border as an explanatory variable has been demonstrated to be a powerful tool in disentangling bird habitat use patterns (Lee and Marsden 2008). We consider that ensuring conservation of vegetation patches that allow seasonal movements of the species will enhance its survival probabilities during this part of its annual cycle. In order to achieve this goal we recommend two avenues of research: (I) patch occupancy analyses to determine minimum forest tract size appropriate for Black-breasted Puffleg, and (2) remote sensing analyses of forest tract connectivity to allow the identification of corridors and enable reserve design. This information is urgently needed since appropriate habitat on the north-western flanks of Pichincha volcano is severely fragmented and forest cover is likely being reduced at a rapid rate (Jahn and Santander 2008). On the other hand, despite the fact that the species seems not to be sensitive to forest structure variables, this information might be complemented by detailed floristic analyses at the presence plots. During our research we noted that Ericaceae species, such as Macleania sp. and Disterigma sp. were often found at presence plots; in fact among the 29 plant species the species is known to feed on, eight belong to the Ericaceae family. Our results are limited to an annual cycle snapshot of habitat use by the Black-breasted Puffleg; further research needs to address critical habitat requirements, for instance during the breeding season which probably occurs between October and March at higher elevations (Jahn 2008). In addition, we still need to determine if sexdriven habitat segregation occurs in the species, as has been reported in other bird species where different habitat types exhibited different proportions of males and females (Marra and Holmes 2001). We trust that accumulating knowledge on Black-breasted Puffleg ecology will help to identify those factors promoting the species' decline over the last several decades and mitigate them.

\section{Supplementary Material}

The online supplementary materials for this article can be found at journals.cambridge.uk/bci

\section{Acknowledgements}

We deeply thank Aves y Conservación staff for logistical support. Rolando Hipo, Olaf Jahn, and Tatiana Santander provided advice on the study design and execution. Fabián Cupuerán, Rolando Hipo, Juan Carlos Valarezo, and Patricio Mena-Valenzuela collected key record data. For assistance and companionship during field work we are in debt to Melissa Heitmann, Humberto Hipo, and Vinicio Paz. We appreciate the help and reserve access permissions granted by Jocotoco Foundation, Nubesierra Foundation, and Alaspungo Community, while we appreciate their enormous efforts to preserve key habitat for this and other Andean species. Two anonymous reviewers provided thoughtful comments on earlier version of this manuscript. Bird surveys were carried on with funding from EcoFondo (Fondo Ambiental Nacional), whereas habitat sampling was funded by BirdLife's Preventing Extinction Programme supported by the species champion Nick Blackwood. The present paper is part of EAG's MSc study in Tropical Ecology at the University of Amsterdam, which was funded by the Ecuadorian National Secretary of Higher Education, Science, Technology, and Innovation SENESCYT.

\section{References}

BirdLife International (2012) Species factsheet: Eriocnemis nigrivestis. Downloaded from http://www.birdlife.org on 1/10/ 2012.

Bleiweiss, R. and Olalla, M. P. (1983) Notes on the ecology of the Black-Breasted Puffleg on Volcán Pichincha, Ecuador. Wilson Bull. 95: 656-661.
Bolker, B. M., Brooks, M. E., Clark, C. J., Geange, S. W., Poulsen, J. R., Stevens, M. H. H. and White, J. S. (2009) Generalized linear mixed models: a practical guide for ecology and evolution. Trends Ecol. Evol. 24: 127-135.

Bonaccorso, E. and Barreto, G. R. (2002) Microhabitat use by foraging Venezuelan 
Wood-Quails (Odontophorus columbianus). J. Field Ornithol. 73: 318-322.

Boyce, M. S. and McDonald, L. L. (1999) Relating populations to habitats using resource selection functions. Trends Ecol. Evol. 14: 268-272.

Burnham, K. P. and Anderson, D. R. (2002) Model selection and multimodel inference. A practical information-theoretic approach. 2nd Edition. New York, USA: Springer-Verlag.

Cahill, J. R. A. and Matthysen, E. (2007) Habitat use by two specialist birds in high-Andean Polylepis forests. Biol. Conserv. 140: 62-69.

Chase, J. M., Kraft, N. J. B., Smith, K. G., Vellend, M. and Inouye, B. D. (2011) Using null models to disentangle variation in community dissimilarity from variation in $\alpha$-diversity. Ecosphere 2: 1-11.

Cortes-Diago, A., Ortega, L. A., MazariegosHurtado, L. and Weller, A. (2007) A new species of Eriocnemis (Trochilidae) from southwest Colombia. Ornitol. Neotrop. 18: 161-170.

Freile, J. F. and Santander, T. (2005) Áreas importantes para la Conservación de las Aves en Ecuador. Quito, Ecuador: Aves y Conservación, BirdLife International, Conservación Internacional y Ministerio del Ambiente de Ecuador.

Graham, M. H. (2003) Confronting multicollinearity in ecological multiple regression. Ecology 84: 2809-2815.

Hagan, J. M., Haegen, Vander, W. M. and McKinley, P. S. (1996) The early development of forest fragmentation effects on Birds. Conserv. Biol. 10: 188-202.

Jahn, O. (2008) Rediscovery of Black-breasted Puffleg Eriocnemis nigrivestis in the Cordillera de Toisán, north-west Ecuador, and reassessment of its conservation status. Cotinga 29: 31-39.

Jahn, O. (2011) Bird communities of the Ecuadorian Chocó: a case study in conservation. Bonner Zoologische Monographien. 56.

Jahn, O. and Santander, T. (2008) Species Action Plan for the Black-breasted Puffleg Eriocnemis nigrivestis. Quito, Ecuador: Aves y Conservación and BirdLife International.

James, F. C. and Shugart, H. (1970) A quantitative method of habitat description. Audubon Field Notes 24: 727-736.
Johnson, D. H. (1980) The comparison of usage and availability measurements for evaluating resource preference. Ecology 61: 65-71.

Kruskal, J. B. (1964) Non-metric multidimensional scaling: a numerical method. Psychometrika 29: 115-129.

Lahti, D. C. (2001) The "edge effect on nest predation" hypothesis after twenty years. Biol. Conserv. 99: 365-374.

Larsden, D. R. (1997) Natural resource biometrics. Downloaded from http://oak.snr. missouri.edu/nr3110/topics/basalarea.html on $1 / 07 / 2012$.

Lee, D. C. and Marsden, S. J. (2008) Increasing the value of bird-habitat studies in tropical forests: choice of approach and habitat measures. Bird Conserv. Internatn. 18: Siog-Si24.

Lemmon, P. E. (1956) A spherical densitometer for estimating forest overstory density. For. Sci. 2: 314-320.

Marini, M. A., Robinson, S. K. and Heske, E. J. (1995) Edge effects on nest predation in the Shawnee National Forest, southern Illinois. Biol. Conserv. 74: 203-213.

Marra, P. P. and Holmes, R. T. (2001) Consequences of dominance-mediated habitat segregation in American Redstarts during the non-breeding season. The Auk 118: 92-104.

Martin, T. E. (2001) Abiotic vs. biotic influences on habitat selection of coexisting species: climate change impacts? Ecology 82: 175-188.

McClure, C. J. W., Rolek, B. W. and Hill, G. E. (2012) Predicting occupancy of wintering migratory birds: is microhabitat information necessary? Condor 114: 482-490.

McWilliams, S. R., Guglielmo, C., Pierce, B. and Klaassen, M. (2004) Flying, fasting, and feeding in birds during migration: a nutritional and physiological ecology perspective. J. Avian Biol. 35: 377-393.

MDMQ-Secretaría de Ambiente (2011) Memoria técnica del mapa de cobertura vegetal del Distrito Metropolitano de Quito (DMQ). Quito, Ecuador: Municipio del Distrito Metropolitano de Quito.

Murcia, C. (1995) Edge effects in fragmented forests: implications for conservation. Trends Ecol. Evol. 10: 58-62.

Oksanen, J., Blanchet, G., Kindt, R., Legendre, P., Minchin, P. R., O'Hara, R. B., Simpson, P. S., 
Henry, M., Stevens, H. and Wagner, H. (2012) Vegan: Community ecology package. $\mathrm{R}$ package version 2.0-3.

Oppel, S., Schaefer, H. M., Schmidt, V. and Schröder, B. (2004) Habitat selection by the Pale-headed Brush-finch (Atlapetes pallidiceps) in southern Ecuador: implications for conservation. Biol. Conserv. 118: 33-40.

R Development Core Team. (2011) R: a language and environment for statistical computing. Vienna, Austria: R Foundation for Statistical Computing.

Raup, D. and Crick, R. E. (1979) Measurement of faunal similarity in paleontology. J. Paleontol. 53: 1213-1227.

Ridgely, R. S. and Greenfield, P. (2001) The birds of Ecuador: Status distribution and taxonomy. New York, USA: Cornell University Press.

Sarkar, D. (2008) Lattice: Multivariate data visualization with $R$. New York, USA: Springer.

Schuchmann, K., Weller, A. and Heynen, I. (2001) Systematics and biogeography of the Andean genus Eriocnemis (Aves: Trochilidae). J. Ornithol. 142: 433-481.

Shapiro, S. S. and Wilk, M. B. (1965) An analysis of variance test for normality (complete samples). Biometrika 52: 591-611.
Sheth, S. N., Loiselle, B. A. and Blake, J. G. (2009) Phylogenetic constraints on finescale patterns of habitat use by eight primate species in eastern Ecuador. J. Trop. Ecol. 25: $571-582$.

Sierra, R. (1999) Propuesta preliminar de un sistema de clasificación de vegetación para el Ecuador Continental. Quito, Ecuador: Proyecto Instituto Ecuatoriano Forestal y de Áreas Naturales y de Vida Silvestre/ Global Environmental Facility, EcoCiencia.

Soursa, P., Helle, H., Koivunen, V. Huhta, E., Nikula, A. and Hakkarainen, H. (2004) Effects of forest patch size on physiological stress and immunocompetence in an areasensitive passerine, the Eurasian treecreeper (Certhia familiaris): an experiment. Proc. $R$. Soc. Lond. B 271: 435-440.

Stevens, R. D. and Willig, M. R. (2000) Community structure, abundance, and morphology. Oikos 88: 4-56.

Venables, W. N. and Ripley, B. D. (2002) Modern applied statistics with $S$. Fourth edition. New York, USA: Springer.

Zuur, A. F., Ieno, E. N., Walker, N. J., Saveliev, A. A. and Smith, G. M. (2009) Mixed effects models and extensions in ecology with $R$. New York, USA: Springer.

\section{ESTEBAN A. GUEVARA*}

Área de Investigación y Monitoreo de Avifauna, Aves y Conservación - BirdLife in Ecuador. Pasaje Joaquín Tinajero E3-05 y Jorge Drom. Casilla 17-17-906, Quito, Ecuador and Institute for Biodiversity and Ecosystem Dynamics, Universiteit van Amsterdam, Science Park, 1098 HX, Amsterdam, The Netherlands.

\section{ELISA BONACCORSO}

Centro de Investigación en Biodiversidad y Cambio Climático, Universidad Tecnológica Indoamérica, Machala y Sabanilla, Quito, Ecuador.

\section{JOOST F. DUIVENVOORDEN}

Institute for Biodiversity and Ecosystem Dynamics, Universiteit van Amsterdam, Science Park, 1098 HX, Amsterdam, The Netherlands.

${ }^{*}$ Author for correspondence; e-mail: eguevara@avesconservacion.org

Received II February 2014; revision accepted 30 September 2014; Published online 13 January 2015 